\title{
Quality of life of patients with hepatitis C
}

\author{
Grazielle Arruda Alves ${ }^{[1]}$, Maria Zélia Baldessar ${ }^{[2]}$, Gregório Wrublevski Pereira ${ }^{[1]}$, \\ Valdete Meurer Kuehlkamp ${ }^{[3]}$, Clarissa Hilzendeger ${ }^{[3]}$ and Jane da Silva ${ }^{[2],[3]}$
}

[1]. Curso de Graduação em Medicina, Universidade do Sul de Santa Catarina, Tubarão, SC. [2]. Departamento de Medicina, Universidade do Sul de Santa Catarina, Tubarão, SC. [3]. Programa de Pós Graduação em Ciências da Saúde, Universidade do Sul de Santa Catarina, Tubarão, SC.

\begin{abstract}
Introduction: Self-report on the quality of life (QOL) is increasingly studied in the evaluation of various diseases, especially in chronic ones. However, there are few data in the literature focusing the QOL of patients living with chronic hepatitis $\mathrm{C}$. The objective of this study was to evaluate the QOL in patients with hepatitis C assessed by the World Health Organization Quality of Life Assessment (WHOQOL)-bref scale. Methods: One hundred and eight hepatitis C patients attending the Outpatient Healthcare Medical Specialties in Tubarão, State of Santa Catarina, Brazil, were contacted from May 2010 to February 2011. Patients answered the WHOQOL-bref scale and a questionnaire about their treatment and risk factors to hepatitis $\mathrm{C}$ virus (VHC) infection. Results: Although most of patients with chronic hepatitis $\mathrm{C}$ considered their QoL good or very good (58.1\%), 47 (44.8\%) patients were poorly or very poorly satisfied with their health. About the WHOQOL answers, the environment domain had the highest score $(25.15 \pm 5.77)$, while the lowest score was the social relationships domain $(9.19 \pm 2.5)$. There was statistically significant association between household income and quality of life in all domains $(p<0.001)$ and statistically significant association between education and the physical, psychological and social domains of quality of life $(p<0.05)$. Conclusions: Based on the answers given in WHOQOL-bref, patients with chronic hepatitis C have a generally poor QOL, especially in social relationship domain. Household income and educational level were factors that interfered significantly with patients' QOL assessment.
\end{abstract}

Keywords: Quality of life. Hepatitis C. Chronic disease.

\section{INTRODUCTION}

The liver disease caused by hepatitis C virus (HCV) is predominantly chronic in the Americas with an estimated prevalence of $1.5 \% \%^{1,2}$. The incidence is higher in underdeveloped or developing regions, reaching about 4 to $6 \%$ in some African communities and the Middle East $^{3}$. In Brazil, it is estimated that $1.38 \%$ of the population is infected with $\mathrm{HCV}^{4}$. In Tubarão, a city located in State of Santa Catarina (SC), Brazil, the incidence reached 77.72 cases per 100,000 population ${ }^{5}$.

Chronic diseases, such as that caused by hepatitis $\mathrm{C}$ virus, interfere with the lives of individuals, causing psychological and behavioral changes, which requires the patient to rethink habits and find a way to face this reality ${ }^{6}$. These changes trigger a range of internal conflicts and feelings $\mathrm{s}^{7,8}$. The complexity of the disease and its possible chronic effects have led to the interest in analyzing the impact of this condition and aspects related to quality of life (QOL) that may influence the treatment ${ }^{8}$.

Researchers and health professionals are increasingly concerned with the QOL of patients. Once the QOL of patients is understood, adequate treatment can be adopted by the healthcare providers, a conduct that may influence the outcome of the disease $\mathrm{e}^{9,10}$. The World Health Organization Quality of Life Assessment or WHOQOLbref is a generic self-report QOL assessment of widespread use in epidemiological and clinical studies ${ }^{11}$ and it has already been applied for patients infected by HCV ${ }^{12}$.

\footnotetext{
Address to: Dra. Jane da Silva. PPG-CS/UNISUL. Avenida José Acácio Moreira 787, Bairro Dehon, 88704-900 Tubarão, SC, Brasil.

Phone: 5548 3621-3363 Fax: 5548 3621-3365

e-mail: janedasilva1808@gmail.com

Received in 12/12/2011 Accepted in 12/04/2012
}

Little is known about QOL of people living with chronic hepatitis in Brazil and there is no report about this subject in Tubarão-SC. Thus, the aim of this study is to assess QOL of chronic hepatitis $C$ virus infected patients from Tubarão-SC, through the WHOQOL-bref.

\section{METHODS}

A cross-sectional study was performed including 105 patients with treated or non-treated hepatitis C, attending the Outpatient Healthcare Medical Specialties (Ambulatório Médico de Especialidades - AME) of the University of Southern Santa Catarina (UNISUL), the Hospital Nossa Senhora da Conceição (HNSC) and a private reference clinics for infectious diseases (Clínica e Consultoria de Doenças Infecciosas CCDI) in Tubarão-SC. Chronic hepatitis C was defined as infection with the hepatitis $C$ virus persisting for more than six months based on the presence of its RNA Hepatitis $C$ and serum immunoglobulin $\mathrm{G}(\mathrm{IgG})$ anti-HCV. Patients co-infected by human immunodeficiency virus (HIV) and/or hepatitis B virus (HBV) were excluded of the study. Data were collected between May 2010 and February 2011.

Patients were asked about sociodemographic characteristics such as age, gender, marital status, education, household income, current and prior (before 12 months) use of drugs such as alcohol, cigarette smoking and injectable drugs by single direct questions (Have you ever taken alcohol/smoked/used injectable drugs in the last 12 months? and Have you ever taken alcohol/smoked/used injectable drugs before the last 12 months?). Regarding blood transfusions, previous or ongoing treatment for hepatitis $\mathrm{C}$ and co-morbidities as diabetes mellitus, hypertension, thyroid diseases and cancer were collected along with the WHOQOL-bref ${ }^{13,14}$. Questionnaires were self-administered, but they were filled in the presence of the interviewers in order to minimize errors.

Epi-Info 6.04 software was used for data analysis. The WHOQOLbref questionnaire was analyzed according to the recommended statistical model that determines the raw and transformed scores 
calculated for each subject (4-20 and 0-100, respectively). The collective score, also known as domain performance, was obtained by grouping the answers. The WHOQOL-bref methodology originally used a 5-point Likert-type scale. Given the diversity of the results' interpretation, we chose to use the modified scale, previously validated, which place the data evenly, favoring comparative analysis in terms of performance of each of the domains studied, with greater visibility on the results ${ }^{15,16}$. The adapted scale is represented by a real number ranging from zero to 100 . Values between 0 and 40 indicate poor QOL; from 41 to 70 are considered intermediate; and 71 and above indicate high QOL.

Univariate statistical analyses were applied to evaluate the association between sociodemographic characteristics and Qol scores. Pearson's chi-square, Student's $t$ test or ANOVA were used to analyze parametric variables. Kruskal-Wallis analysis was used to analyze non-parametric variables. The $p$-value less than 0.05 was considered significant, and a $95 \%$ confidence interval was established for the differences and associations.

\section{Ethical considerations}

The project of this study was approved by the Research Ethics Committee of UNISUL, under registration number 10.083.4.01.III. All patients signed an informed consent before data collection.

\section{RESULTS}

The study population consisted of 105 patients with chronic hepatitis $C$ diagnosis attending the Outpatient Healthcare Medical Specialties (Ambulatório Médico de Especialidades - AME) of the University of Southern Santa Catarina, the Hospital Nossa Senhora da Conceição (HNSC) and a private reference clinic for infectious diseases (Clínica e Consultoria de Doenças Infecciosas - CCDI).

The sociodemographic data are presented in Table 1.

When patients were asked about social habits, as risk factors to hepatitis C, 56 (53.3\%) and 57 (54.3\%) of them did alcohol consumption and cigarette smoking prior to hepatitis $\mathrm{C}$ diagnosis, respectively. Both habits reduced significantly $(p<0.05)$ after hepatitis diagnosis, being present in $26(24.8 \%)$ and $29(27.6 \%)$ cases, respectively. About other risk factors such as intravenous (IV) drugs use, 19 (18.1\%) answered that they had used it before and 41 (39\%) had received blood transfusions in their life.
TABLE 1 - Profile of patients with hepatitis $C$ according to demographic variables in Tubarão, State of Santa Catarina, Brazil, from May 2010 to February 2011.

\begin{tabular}{lcc}
\hline Variable & Number & Percentage \\
\hline Gender & 50 & 47.6 \\
male & 55 & 52.4 \\
female & & \\
\hline Education (years of schooling) & 61 & 58.1 \\
$\quad$ < years & 40 & 38.2 \\
8 - 11 years & 4 & 3.8 \\
$\geq 12$ years & & \\
\hline Household income (minimum wages) & 44 & 42.0 \\
1 - 2 & 37 & 35.2 \\
3 - 5 & 24 & 22.9 \\
$\geq 6$ & & \\
\hline Marital status & 8 & 7.6 \\
single & 65 & 61.9 \\
married & 5 & 4.8 \\
cohabitating & 10 & 9.5 \\
widow (er) & 17 & 6.2 \\
separated & & \\
\hline
\end{tabular}

Interferon-ribavirin treatment was taking by 37 (35.2\%) of patients, 32 of them were treated with pegylated interferon, while 5 used conventional interferon. When these patients were compared with those treated before or not treated, the QOL was not significantly different.

When asked, How do you rate your QOL? Sixty-one (58.1\%) said they considered it good or very good. About the question, Are you satisfied with your health? Forty-seven (44.8\%) considered it poor or very poor. Table 2 presents the association between the measures of central tendency measurements and QOL domain scores of patients with hepatitis $\mathrm{C}$.

Table 3 shows the mean scores of sociodemographic variables, according to answers of patient to WHOQOL-bref. In general, all domains had poor scores (less than 40), reflecting a poor QOL.

The relationship between household income, education, treatment and quality of life and WHOQOL-bref scale is showed in Table 4. Median, $25 \%$ percentile and $75 \%$ percentile of household income and education compared with quality of life are showed in Table 5.

TABLE 2 - Quality of life domain scores of the WHOQOL-bref scale in patients with hepatitis C in Tubarão, State of Santa Catarina, Brazil, from May 2010 to February 2011.

\begin{tabular}{|c|c|c|c|c|}
\hline Domains & Mean & Standard deviation & Minimum & Maximum \\
\hline Physical & 20.80 & 3.18 & 14 & 27 \\
\hline Psychological & 18.56 & 3.29 & 9 & 25 \\
\hline Social relationships & 9.19 & 2.50 & 3 & 14 \\
\hline Environmental & 25.15 & 5.77 & 12 & 40 \\
\hline
\end{tabular}

WHOQOL-bref: World Health Organization Quality of Life Assessment. 
TABLE 3 - Mean scores of the WHOQOL-bref scale relating the sociodemographic questionnaire in patients with hepatitis C, in Tubarão, State of Santa Catarina, Brazil, from May 2010 to February 2011.

\begin{tabular}{|c|c|c|c|c|c|c|c|c|}
\hline Variable & Psychological & $\mathbf{p}$ & Physical & $\mathbf{p}$ & Social & $\mathbf{p}$ & Environment & $\mathbf{p}$ \\
\hline \multicolumn{9}{|l|}{ Gender } \\
\hline male & 18.74 & NS & 21.00 & NS & 10.00 & NS & 25.00 & NS \\
\hline female & 18.40 & & 20.63 & & 10.00 & & 25.00 & \\
\hline Household income & & $<0.05$ & $<0.001$ & & $<0.01$ & & $<0.01$ & \\
\hline $1-2 \mathrm{MW}$ & 17.81 & & 19.27 & & 8.23 & & 23.11 & \\
\hline $3-5 \mathrm{MW}$ & 18.88 & & 21.27 & & 9.52 & & 26.27 & \\
\hline $6-8 \mathrm{MW}$ & 19.70 & & 22.10 & & 10.00 & & 26.70 & \\
\hline $9-11 \mathrm{MW}$ & 18.81 & & 23.18 & & 10.54 & & 27.63 & \\
\hline$\geq 12 \mathrm{MW}$ & 20.00 & & 22.33 & & 10.66 & & 26.00 & \\
\hline Education (years) & & $<0.05$ & & $<0.001$ & & $<0.01$ & & NS \\
\hline$<8$ & 18.26 & & 19.83 & & 8.56 & & 24.53 & \\
\hline 8-11 & 18.97 & & 22.05 & & 10.00 & & 25.85 & \\
\hline$\geq 12$ & 19.00 & & 23.50 & & 10.50 & & 27.50 & \\
\hline Alcohol consumption in the past 12 months & & NS & & NS & & NS & & NS \\
\hline yes & 17.80 & & 20.15 & & 8.61 & & 23.15 & \\
\hline no & 18.82 & & 21.02 & & 9.38 & & 25.82 & \\
\hline Previous alcohol consumption & & NS & & NS & & NS & & NS \\
\hline yes & 18.39 & & 20.89 & & 9.30 & & 24.32 & \\
\hline no & 18.77 & & 20.70 & & 9.06 & & 26.12 & \\
\hline Injectable drugs & & NS & & NS & & NS & & NS \\
\hline yes & 18.27 & & 21.50 & & 9.61 & & 24.55 & \\
\hline no & 18.62 & & 21.00 & & 9.10 & & 25.27 & \\
\hline Current concomitant diseases & & NS & & NS & & NS & & NS \\
\hline yes & 18.66 & & 20.35 & & 8.90 & & 24.92 & \\
\hline no & 18.47 & & 21.27 & & 9.49 & & 25.39 & \\
\hline Underwent hepatitis C treatment & & NS & & NS & & NS & & NS \\
\hline yes & 18.68 & & 20.68 & & 8.93 & & 24.35 & \\
\hline no & 18.29 & & 21.09 & & 9.80 & & 27.03 & \\
\hline
\end{tabular}

MW: minimum wage; NS: not significant; WHOQOL-bref: World Health Organization Quality of Life Assessment.

TABLE 4 - Mean scores of the WHOQOL-bref scale comparing household income, education level and treatment with quality of life of patients with hepatitis $C$ in Tubarão, State of Santa Catarina, Brazil, from May 2010 to February 2011.

\begin{tabular}{lcccc}
\hline & Mean & Median & Standard deviation & $\mathbf{p}$ \\
\hline Income & & & & $<0.001$ \\
1- 2 MW & 75.02 & 74.00 & 15.94 & \\
3-5 MW & 82.22 & 83.00 & 10.60 & \\
$\quad$ 6 MW & 85.33 & 87.00 & 5.84 & $<0.05$ \\
\hline Education (years)* & & & & \\
$<8$ & 73.55 & 74.00 & 14.33 & \\
8 - 11 & 81.32 & 83.00 & 13.08 & $\mathrm{NS}$ \\
$\quad$ 12 & 83.75 & 87.00 & 7.02 & \\
\hline Treatment & & & & \\
$\quad$ yes & 79.03 & 12.83 & 79.00 & \\
no & 80.44 & 13.14 & 82.00 & \\
\hline
\end{tabular}

MW: minimum wage; NS: not significant; WHOQOL-bref: World Health Orga-nization Quality of Life Assessment *years of schooling.

\section{DISCUSSION}

Information on QOL has been increasingly studied and instruments as WHOQOL-bref, which use questions divided into
TABLE 5 - Median, 25\% percentile and 75\% percentile of household income and education level compared with quality of life of patients with hepatitis C in Tubarão, State of Santa Catarina, Brazil, from May 2010 to February 2011.

\begin{tabular}{lcccc}
\hline & $\mathbf{2 5 \%}$ & Median & $\mathbf{7 5 \%}$ & $\mathbf{p}$ \\
\hline Household income & & & & $<0.05$ \\
1- 2 MW & 61.0 & 74.0 & 85.0 & \\
3-5 MW & 76.5 & 83.0 & 90.5 & \\
6-8 MW & 81.0 & 87.0 & 88.0 & \\
9-11 MW & 82.0 & 88.0 & 91.0 & \\
>12 MW & 76.0 & 89.0 & 89.0 & \\
\hline Education & & & & $<0.05$ \\
<8 years & 66.5 & 79.0 & 88.0 & \\
8-11 years & 78.0 & 87.0 & 89.0 & \\
>12 years & 82.5 & 89.0 & 90.0 & \\
\hline
\end{tabular}

MW: minimum wage; Education: years of schooling.

domains (physical, social, environmental and psychological) ${ }^{11}$, can help to better understand the multidimensionality that defines $\mathrm{QOL}^{17}$. When the QOL is evaluated in a specific disease, the follow up of patients is broader and even the treatment adopted by the health team can be influenced and modified ${ }^{12}$. 
Regarding hepatitis infection, it means that the diagnosis of hepatitis C influence negatively the QOL of patients. One study showed significant lower QOL scores in all domains among those who knew the hepatitis $C$ diagnosis compared with those who did not ${ }^{18}$. Even though most patients in our study said they have a good or very good QOL, almost $45 \%$ of the cases considered their health bad or very bad. Analyzing each domain of WHOQOL-bref, the lower score was in social relationship component. The poor quality of life in this domain may reflect the impact of the hepatitis diagnosis per se, because chronic infections like hepatitis can limit social relationship in some aspects.

There was a statistically significant association between income and education level with QoL, implying that low income and a low education level is associated with a poorer QoL. In fact, with sociodemographic variables, such as income, marital status, age or education, co-morbidities had important effects on global QoL of patients living with hepatitis $C^{19,20}$. Because of the close relationship between income and education, it is not easy to discuss specifically the influence of hepatitis $C$ in the association between low income or education level and poor QoL found in this study. More studies searching to explain better these points are needed.

About social habits, a recent study showed that the concomitant use of tabacco and alcohol by patients with hepatitis $C$ promotes a significant negative impact on their QOL, especially in the presence of depression, fatigue, difficulty in sleeping and loss of interest in $\operatorname{sex}^{21}$. In this study, the alcohol consumption and smoking habits significantly changed after hepatitis $C$ diagnosis. This may indicate that patients diagnosed with hepatitis $\mathrm{C}$ become more attentive to their health and liver conditions. At least about reduction of alcohol use, this finding is consistent with a study made in Australia, which showed that patients aware of the liver disease diagnosis were less likely to drink. Probably, it reflects that the patient is following the medical advice given at the time of the diagnosis ${ }^{18}$.

Although the WHOQOL-bref showed to be an easy questionnaire to evaluate the QOL of the patients living with chronic hepatitis $C$, the instrument is not specific for this disease and it may limit its interpretation. Aspects related to the time of diagnosis and staging of the disease, as well as crack and/or marijuana use and psychiatric diseases associated were not investigated and it represents another limitation of this study.

Patients with hepatitis $\mathrm{C}$ showed a significant reduction of QOL globally, especially in social relationships domain. Household income and educational level were factors that interfered significantly with patients' QOL assessment. Because of the close relationship between income and education, further studies looking better explain the association between these variables and QOL in hepatitis $C$ are needed.

\section{ACKNOWLEDGMENTS}

We thank the Hospital Nossa Senhora da Conceição (HNSC), Ambulatório de Especialidades Médicas (AME) and Clínica e Consultoria de Doenças Infecciosas (CCDI) in Tubarão, State of Santa Catarina, for providing access to information regarding patients with hepatitis C. We also thank Thiago Casagrande do Canto and Gustavo Arruda Alves for helping to collect data for this study.

\section{CONFLICT OF INTEREST}

The authors declare that there is no conflict of interest.

\section{ABSTRACT IN PORTUGUESE}

\section{Qualidade de vida de pacientes com hepatite C}

Introdução: O autorrelato sobre a qualidade de vida (QV) é cada vez mais estudado na avaliação de várias doenças, especialmente nas crônicas. No entanto, existem poucos dados na literatura focando a QV de pacientes vivendo com hepatite C crônica. O objetivo deste estudo foi avaliar a QV em pacientes com hepatite $C$ através da escala World Health Organization Quality of Life Assessment versão breve (WHOQOL-bref). Métodos: Foi feito contato com 108 pacientes de hepatite $\mathrm{C}$ que frequentavam o Ambulatório Médico de Especialidades em Tubarão, Santa Catarina, Brasil, de maio de 2010 a fevereiro de 2011. Os pacientes responderam ao WHOQOLbref e a um questionário sobre o seu tratamento e fatores de risco à infecção pelo vírus da hepatite C (VHC). Resultados: Embora a maioria dos pacientes com hepatite $C$ crônica considerasse sua QV boa ou muito boa $(58,1 \%), 47(44,8 \%)$ dos pacientes estavam nada ou muito pouco satisfeitos com a sua saúde. Sobre as respostas do WHOQOL, o domínio ambiental obteve o escore mais alto $(25,15 \pm 5,77)$, enquanto o menor escore foi do domínio relações sociais $(9,19 \pm 2,5)$. Houve associação estatística significativa entre renda familiar e qualidade de vida em todos os domínios $(p<0,001)$ e associação estatística significativa entre educação e os domínios físico, psicológico e social da qualidade de vida $(p<0,05)$. Conclusões: Baseado nas respostas dadas no WHOQOL-bref, pacientes com hepatite C crônica têm uma QV geralmente pobre, especialmente no domínio relações sociais. A renda familiar e o nível de educação foram fatores que interferiram significativamente na auto-avaliação da qualidade de vida dos pacientes.

Palavras-chaves: Qualidade de vida. Hepatite C. Doença crônica.

\section{REFERENCES}

1. Brandão $A B$, Fuchs SC, Silva MA, Emer LF. Diagnosis of hepatitis $C$ in clinical practice: review of the literature. Rev Panam Salud Publica 2001; 9:161168.

2. World Health Organization. Hepatitis C [Internet]. [Cited 2009 November 11] Available from: www.who.int/mediacentre/factsheets/fs164/en/.

3. Shepard CW, Finelli L, Alter MJ. Global epidemiology of hepatitis C virus infection. Lancet Infect Dis 2005; 5:558-567.

4. Ministério da Saúde. Secretaria de Vigilância em Saúde. Departamento de DST, Aids e Hepatites Virais. Boletim epidemiológico: hepatites virais. Brasília: Ministério da Saúde; 2011.

5. Secretaria do Estado da Saúde de Santa Catarina, Sistema Único de Saúde, Diretoria de Vigilância Epidemiológica, Programa estadual de hepatites virais. Estruturação de serviços de referência para realização de biópsia hepática no Estado de Santa Catarina. 2006 May; p. 1-4. [Cited 2010 January 20] Available from: www.dive.sc.gov.br/conteudos/imunizacao/ noticias/MutiraoBIOPSIA2.pdf/.

6. Araújo ESA. Hepatite C. In: Cimerman S, Cimerman B, editors. Condutas em infectologia. São Paulo (SP): Atheneu; 2004. p. 113-121.

7. Sousa VV, Cruvinel KPS. Ser portador de hepatite C: sentimentos e expectativas. Texto Contexto Enferm 2008; 17:689-695.

8. Martins LM, França APD, Kimura M. Qualidade de vida de pessoas com doença crônica. Rev Latino Am Enfermagem 1996; 4:5-18.

9. Kaplan RM. Quality of life, resource allocation, and the U.S. health - care crisis. In: Dimsdale JE, Baum A, editors. Quality of life in behavioral 
medicine research. New Jersey: Lawrence Erlbaum Associates; 1995. p. 3-30.

10. Morris J, Perez D, McNoe B. The use of quality of life data in clinical practice. Qual Life Res 1998; 7: 85-91.

11. The WHOQOL Group. The World Health Organization quality of life assessment (WHOQOL): development and general psychometric properties. Soc Sci Med 1988; 46:1569-1585.

12. Taliani G, Rucci P, Biliotti E, Cirrincione L, Aghemo A, Alberti A, et al. Therapy expectations and physical comorbidity affect quality of life in chronic hepatitis C virus infection. J Viral Hepatol 2007; 14:875-882.

13. Fleck MPA, Leal OF, Louzada S, Xavier M, Chachamovich E, Vieira G, et al. Desenvolvimento da versão em português do instrumento de avaliação da qualidade de vida da OMS (WHOQOL - 100). Rev Bras Psiquiatr 1999; 21:19-28.

14. Fleck MP, Louzada S, Xavier M, Chachamovich E, Vieira G, Santos L, et al. Aplicação da versão em português do instrumento abreviado de avaliação da qualidade de vida WHOQOL-bref. Rev Saude Publica 2000; 34 178-183.
15. Saupe R, Nietche EA, Cestari ME, Giorgi MDM, Krahl M. Qualidade de vida dos acadêmicos de enfermagem. Rev Latino-Am Enfermagem 2004; 12:636-642.

16. Spínola MR, Pereira EM. Avaliação de programas: uma metodologia. Projeção 1976; 7:26-32.

17. Seidl EMF, Zannon CMLC. Qualidade de vida e saúde: aspectos conceituais e metodológicos. Cad Saude Publica 2004; 20:580-588.

18. Rodger AJ, Jolley D, Thompson SC, Lanigan A, Crofts N. The impact of diagnosis of hepatitis C virus on quality of life. Hepatology 1999; 30:1299-1301.

19. Chong CA, Gulamhussein A, Heathcote EJ, Lilly L, Sherman M, Naglie G, et al. Health-state utilities and quality of life in hepatitis $C$ patients. Am J Gastroenterol 2003; 98:630-638.

20. Helbling B, Overbeck K, Gonvers JJ, Malinverni R, Dufour JF, Borovicka J, et al. Host- rather than virus-related factors reduce health-related quality of life in hepatitis C virus infection. Gut 2008; 57:1597-1603.

21. Yamini D, Basseri B, Chee GM, Arakelyan A, Enayati P, Tran TT, et al. Tobacco and other factors have a negative impact on quality of life in hepatitis $C$ patients. J Viral Hepat 2011; 10:714-720. 